J. Asiat. Soc. Bangladesh, Sci. 45(1): 15-33, June, 2019

\title{
DIVERSITY AND ABUNDANCE OF PTEROPODS ALONG THE SAINT MARTIN'S ISLAND AND ITS EFFECTS ON ECOLOGY OF BAY OF BENGAL, BANGLADESH
}

\author{
S.K. SAHA*, NAHID IBN MUZIB AND MAHMUD AL NOOR TUSHAR \\ Department of Geology, University of Dhaka, Dhaka-1000, Bangladesh
}

\begin{abstract}
The study deals with pteropods which is an important group of Holoplanktonic mollusks belonging to the class Gastropod. The study attempted to disclose the available pteropods in this region and to attain a clear concept of their abundance and diversity in and around Saint Martin's Island. The study also attempted to establish pteropods as another significant environmental indicator along with other microfossils in this region. Among the 41 identified species included both Thecosomata and Gymnosomata orders with having a total of 17 families and 19 genera were described. The study was conducted from the ferry ghat to Uttar para and Dakkshin para and covering to the southernmost part of Chera Dwip of the Saint Martin's island. The study also reveals the diversity and variation of the species with the gradual distance and water depth from land to ocean area. The study identified both the freshwater and Pelagic pteropods. Abundance of Thecosomes was a significant finding which can boost in further studies on ocean acidification in Saint Martin's island of Bay of Bengal.
\end{abstract}

Key words: Pteropods, Ocean acidification, Bay of Bengal, Saint Martin's Island

\section{Introduction}

St. Martin's Island is a small coral island in the north-eastern part of the Bay of Bengal, about $9 \mathrm{~km}$ south of Cox's Bazar-Teknaf Peninsular tip and forms the southernmost tip of Bangladesh (Afrin et al. 2013). The area of the island is about $5.9 \mathrm{~km}^{2}$ whereas with the rocky platforms extending into the sea. The total area of the island is about $12 \mathrm{~km}^{2}$. It was connected to the mainland of the Teknaf Peninsula as recently as 6,000-7,000 years ago (Warrick et al. 1993, Chowdhury 2012).

The coral community in St. Martin's Island supports associated fish and invertebrate fauna characteristics of coral reef environment. The most abundant group of invertebrate found in the coral bed are mollusks. About 61 species of them have been identified so far. Besides 9 species of Echinoderms, 4 species of Zonathids and 4 species of Bryzoans are also present here (Tomascik 1997, DoZ 1997).

*Author for correspondence: <sks@du.ac.bd>. 
Pteropods were first described as a group in 1804 by Georges Cuvier. Pteropods are a group of heterobranch gastropods - a superorder comprised of the orders Thecosomata, also referred to as "sea butterflies", and Gymnosomata, or "sea angels" that play an important role in marine food webs (Lalli and Gilmer 1989). Pteropods are found throughout the world's ocean and are holoplanktonic that means they spend their entire life cycle in the open water column. Pteropod tests are limited to shallow tropical and subtropical oceanic regimes such as the Arabian Sea (e.g. Herman and Rosenberg 1969, Singh and Rajarama 1997, Singh et al.2001) and to marginal seas such as the Red Sea and the Mediterranean Sea (Reiss et al. 1980, Almogi-Labin 1982, Almogi-Labin et al.1991, Wang et al. 1995). They represent an extraordinary diversity in morphological forms and can be numerically and functionally important components of marine food webs (Lalli and Gilmer 1989). Shelled pteropods affect the ocean carbon cycle by producing aragonite shells that can accelerate the export of organic matter from the surface into the deep ocean. Because of their delicate aragonite shells, pteropods have been identified as extremely vulnerable to the effects of ocean acidification (Feely et al. 2009).

The distribution of pteropods is mainly influenced by the depth of the ocean (van Straten 1972). The abundance of pteropods within different water masses depend upon specific physico-chemical properties and by the adaptive potential of different individual species. Thecosome pteropods depend on the process of calcification to grow their shells which consist of aragonite and calcium carbonate. Hence the saturation of carbonate ions in the water is vital to their survival. Their body is made up of an aragonite and calcium carbonate shell; they are very sensitive to ocean acidification driven by the increase of anthropogenic $\mathrm{CO}_{2}$ emissions and other oceanic processes (Comeau et al. 2009) and also play a key role in the cycling of carbon and carbonate. The recent research on pteropods mainly focuses on their susceptibility to ocean acidification (Fabry et al. 2008).

The studies of pelagic pteropods from the Arabian Sea and Bay of Bengal were very meagre and most of the studies concentrated on ecological or fossil studies not in a taxonomic point of view. Most of the fossil studies of pteropods are from the Arabian Sea or from the Andaman Sea within the EEZ of India (Berner 1977). In the Bay of Bengal, the pelagic studies were done by Aiyar et al. (1936) from Madras, Arabian Sea (Sakthivel 1976), Eastern Bay of Bengal, around Tillachang Island and the paleontological studies from the Andaman Sea (Bhattacharjee et al. 2002 and Bhattacharjee 2005).

A micropaleontological investigation of the fossils present in Saint Martin's Island can give some important information and ideas about the past paleo-climatic condition and its 
sequential changes from past to present. The main objectives of this research was to identify the systematic description of the pteropods as well as to infer the ecological consideration and distribution of the species.

\section{Materials and Methods}

Saint Martin's Island is a small island in the northeast of the Bay of Bengal. The island is $7.315 \mathrm{~km}$ long and is aligned NNW and SSE. For the purpose of conducting a micropalaeontological investigation and studying the microfossils and their relationships to the climatic change in the past and near future of Saint Martin's island it was necessary to explore the sediments of this area. About 32 samples of 12 locations from Saint Martin and Chera Dwip were collected with GPS location for analysis.

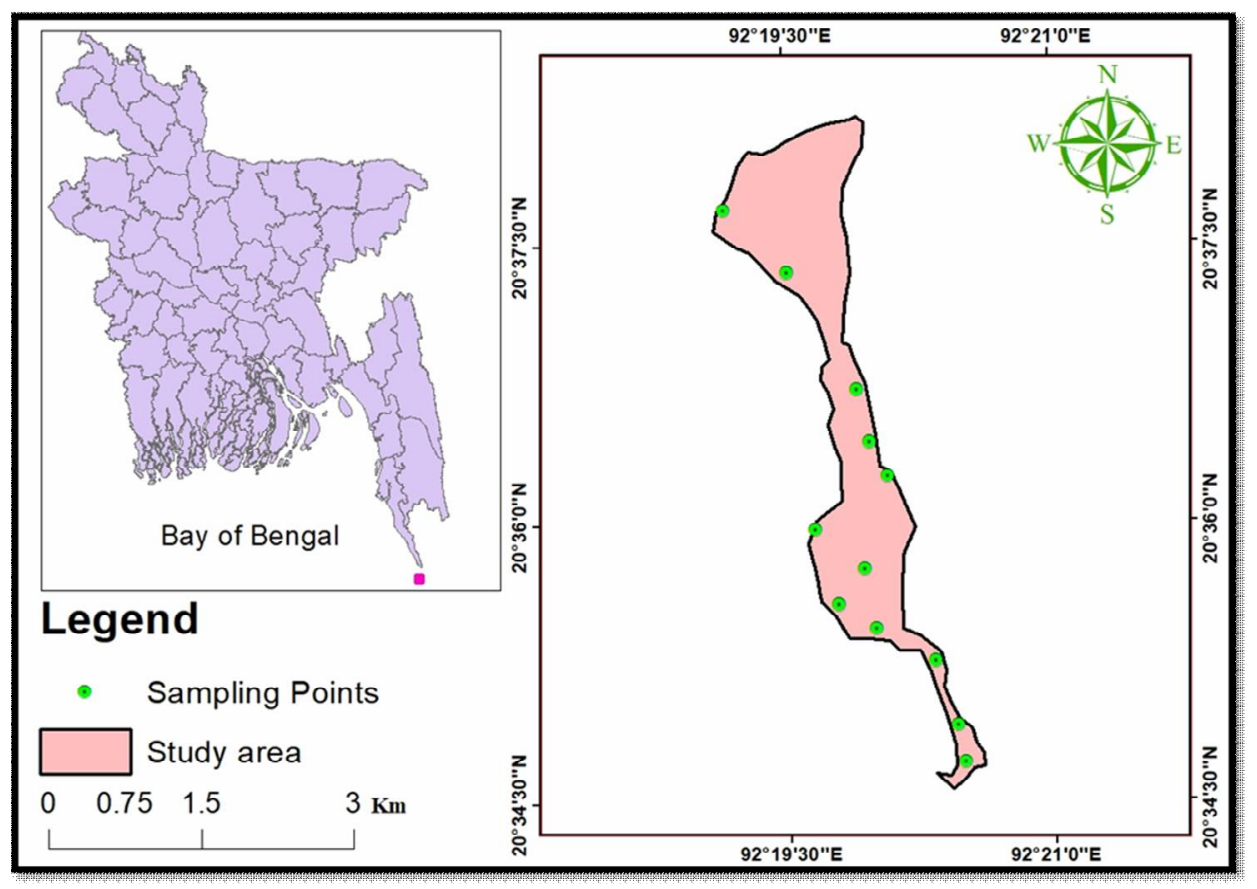

Source: Author's filed survey.

Fig. 1. Location map and sampling points of the study area.

Modern microfossil collection follows standard method (Palmer and Abbott 1986, Gehrels et al. 2002) which is also very familiar to foraminifer's collection. Standard sample volume $\left(10 \mathrm{~cm}^{2}\right.$ by $1 \mathrm{~cm}$ thick) allows comparison with similar studies (e.g. 
Horton et al. 2003). All materials were collected in low tide during a neap tidal cycle. The sampling interval was about $100 \mathrm{~m}$. These samples were sieved retaining the fraction $60,80,120 \mu \mathrm{m}$ and the time interval for all is 10 minute. The 60 and $80 \mu \mathrm{m}$ samples were chosen for microscopic analysis.

The sediments may contain abundant microfauna that can be analyzed with a binocular microscope (Meiji techno EMT2) and photographs were taken by camera built in microscope (Leica EZ4E). The samples selected for microfaunal analysis were prepared by following the protocol justifying their grouping. All the specimens were photographed neatly with camera attached to a binocular microscope` for further detailed analysis.

Geology of the study area: Saint Martin's Island is a dumb-bell shaped sedimentary continental island located on the Eastern flank of an anticline, which like Chittagong may be part of the Arakan-Yoma-Nagafolded system (Warrick et al. 1993). The land of the island is about $8 \mathrm{~km}^{2}$ depending on the tidal level. The island is almost flat with an average height of $2.5 \mathrm{~m}$ above mean sea level (MSL), rising to a maximum of $6.5 \mathrm{~m}$ high cliffs along the eastern coast of Dakshin Para (Ahmed 1995).

The tectonic structure of the island is simple and is represented by an anticlinal uplift. A little of the axis of the anticline is traceable along the west coast of Dakshin para. The exposed portion of the axis runs NNW to SSE, approximately parallel to the island. There is a fault along the northwestern shoreline with a trend nearly parallel to the axis (Banglapedia 2015).

The fault seems to be reverse in nature with the eastern side as the up thrown block. The anticline is slightly asymmetrical with a monoclinal swing on the eastern flank. The bedrock on the eastern flank near the axis dips very gently at an angle of 3 to $5^{\circ}$ towards the east, increasing eastwards to 10 to $12^{\circ}$. The monoclinal swing gives a high dip of $30^{\circ}$ and above at Chheradia. Very little of the western flank is exposed above the sea which records a dip of $6^{\circ}$ towards the west. The monoclinal swing gives the anticline a box-like shape. The birth of the island is related to the regional tectonics of southeast Asia. As a sequel to the most dynamic Himalayan orogeny during Middle Miocene (around 15 million years before) (Banglapedia 2015).

Systematic description: Pteropods (Thecosomata and Gymnosomata) are the groups of holoplanktonic molluscs belonging to the Class Gastropoda. They are commonly called sea butterflies and found in good numbers in zooplankton collections. Of the approximately 50,000 marine species of gastropods only 244 species are holoplanktonic (van der Spoel and Dadon 1997). They are wide spread in the surface waters of open oceans of the tropical, subtropical latitudes (Gilmer and Harbison 1991) Hunt and Hosie 
2006). Their shells are thin, fragile and made up of aragonite and calcium carbonate (Janssen 2005). Empty shells of pteropods constitute a major portion of shallow marine sediments, especially in the tropical and subtropical regions (Herman 1968). During this field investigation, 32 species were finally selected to analyze and the description of the species are stated below.

Phylum: Mollusca

Class: Gastropoda

Subclass: Heterobranchia

Super order: Pteropoda

Order: Thecosomata

Suborder: Eucosomata

Super family: Limacinoidea

Family: Limacinidae

Genus: Limacina

Type species: Limacina atypica (Woodward 1854)

Plate 1, Figs 1, 2 (Uttar para 2 Lat. 20³4' 33"; Lon. 92 $\left.20^{\circ} 13.4^{\prime \prime}\right)$.

Remarks: Shell is small, sinistral with up to four convex whorls, 1.5 to 1.6 times wider than its height and has a flat apical side. The whorls are coiled in a plane spiral. The periphery is evenly rounded. The aperture is obliquely ovoid, slightly indented by the penultimate whorl. Type locality of the specimen is Pakaurangi Point, Kairapara, New Zealand.

\section{Genus: Limacina}

Type species: Limacina inflate

Plate 1, Figs 3, 4 (Uttar para 2 Lat. 20³4' 33"; Lon. 92 20' 13.4").

Remarks: Shell is small (maximum diameter is $1.5 \mathrm{~mm}$ ), sinistral shell with up to three whorls coiled at one level. The last whorl is swollen. Aperture is heart-shaped with blunt tooth extending on the last whorl as faint keel or rib. Rostrum or aperture tooth is variable in shape. Umblicus is deep. The shell is embryonic with rough granulated surface both on proximal zone and the first whorl (Boltoveskoy 1978). Type locality of the specimen is known to be at Atlantic and Pacific Ocean.

\section{Genus: Limacina}

Type species: Limacina heliconoides (Jeffreys 1858)

Plate 1, Fig. 5 (Uttar para 4, Lat. 20³6' 14.8"; Lon. 92 19' 51.7"). 


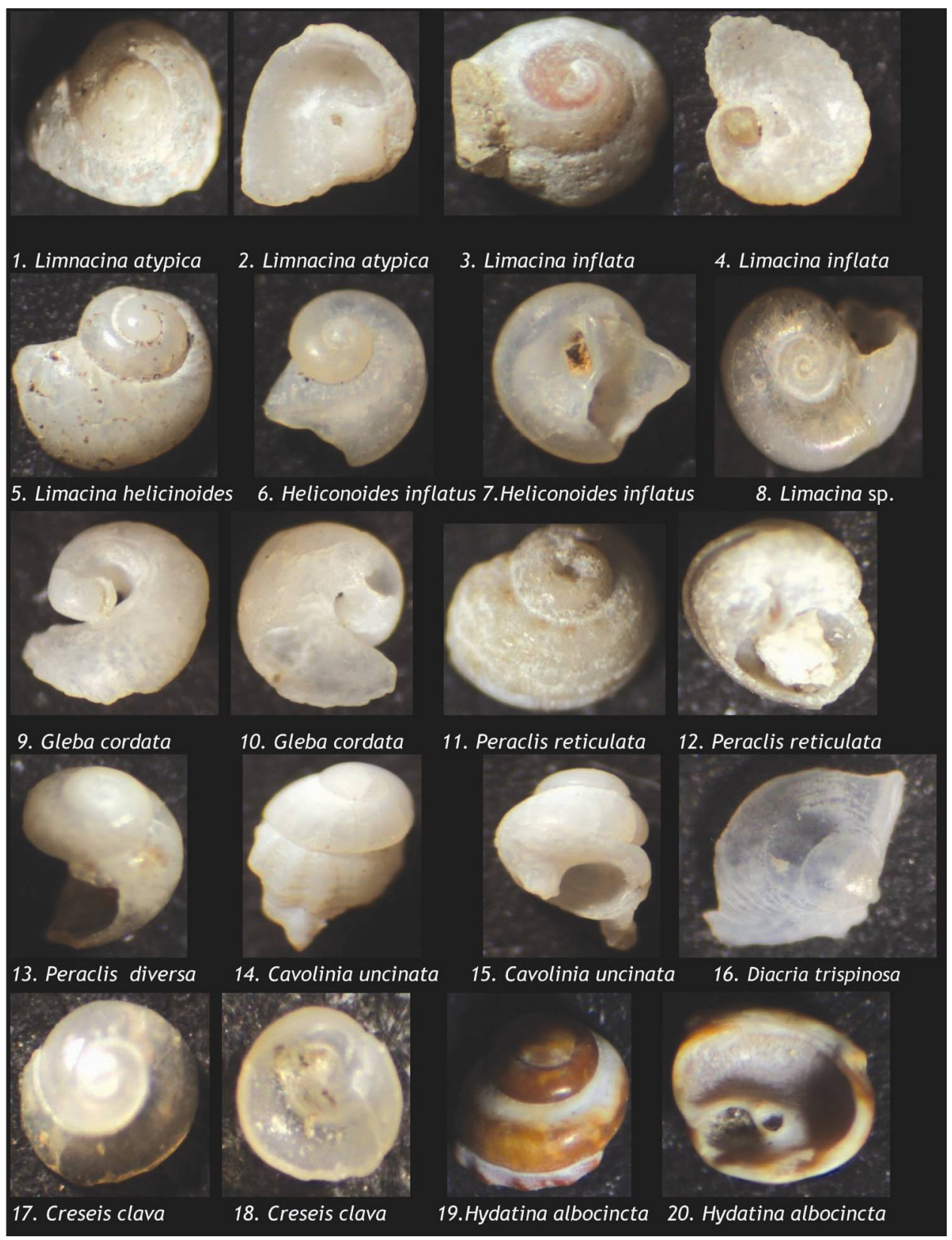

Plate 1. Selected pteropods recovered from Saint Martin' Island. 
Remarks: It has a large chest-nut shell (diameter is about 0.09 to $0.15 \mathrm{~mm}$ ), some spiral lines of punctation are found on the first whorl and on the embryonic shell. Transverse growth lines are found on the last whorl. The shell is depressed with three to four whorls of which the last one is swollen and composes a major part of the shell. The narrow umbilicus is closed or absent. The aperture is oval, higher than its width.This is the only species of Limacina, in which a larval (secondary) shell is followed by a tertiary shell differing in sculpture (not gross rnorphology) and reflecting the time of hatching from the mantle cavity (van der Spoel 1978). This species is mainly found in Atlantic and Pacific Ocean.

\section{Genus: Heliconoides}

Type species: Heliconoidesinflatus

Plate 1, Figs 6, 7 (Uttar para 5, Lat. 20³4' 49"; Lon. 92 20' 11").

Remarks: The size of the species ranges from 0.5 to $3.0 \mathrm{~mm}$. Sinistrally coiled, involute pigmented with two or three whorls. It has large paired fins. Right tentacle is much larger than the left tentacle. Typically ranges from south of Point Conception to as far south as Vizcaino Bay, Mexico.

Genus: Limacina

Type species: Limacina sp.

Plate 1, Fig. 8 (Uttar para 5, Lat. 20³4' 49"; Lon. 92 20' 11").

Remarks: Shell small in genus Limacina (average height $0.7 \mathrm{~mm}$, width $0.9 \mathrm{~mm}$ ), sinistral coiled, with about 3 whorls. Shell height 0.8 maximum width. Spire relatively low, apical angle 145 to $150^{\circ}$. Suture impressed. Apex small, moderately inflated. Umbilicus width 5 to $10 \%$ maximum width. Aperture narrow-oval, higher than width (Yusuke 2011). The morphology is of Limacina sp. is very similar to species belonging to the genus Heliconoides, in particular H. mermuysias. It is found in Caribbean Sea and in the Indian Ocean.

$$
\begin{aligned}
& \text { Super family: Cymbulioidea } \\
& \text { Family: Cymbulioiidae } \\
& \text { Genus: Gleba }
\end{aligned}
$$

Type species: Glebacordata (msForskal) (Niebuhr 1776)

Plate 1, Figs 9, 10 (Uttar para 2', Lat. 20 34' 33.0"; Lon. 92 20' 13.4").

Remarks: This is a shell-less pteropods with a large gelatinous slipper like pseudo conch.The pseudo conch is rounded. Diameter of the swimming plate up to $60 \mathrm{~mm}$, 
length of the pseudo conch up to $45 \mathrm{~mm}$. It is found in warm waters of Atlantic Ocean and Indian Ocean.

Family: Peraclidae

Genus: Peraclis

Type species: Peraclisreticulata (d'Orbigny 1836)

Plate 1, Figs 11, 12 (Cheradip 7, Lat. 20 37' 1.7"; Lon. 92 $12^{\prime} 22.2^{\prime \prime}$ ).

Remarks: Shell is yellowish, relatively high, and horny with three to four whorls and deep suture without radial crest. Spire is not depressed. Keel present, no aperture tooth, aperture wide and oval. Base of the aperture is pointed towards keeled rostrum. Umbilicus is very narrow or absent. Shell height is about $6 \mathrm{~mm}$ and diameter is $3 \mathrm{~mm}$. It is typically found in South Atlantic Ocean.

\title{
Genus: Peracle
}

Type species: Peraclediversa (Monterosato 1875)

Synonym: Peracle bispinosa (Pelseneer 1965)

Plate 1, Fig. 13 (Uttar para 3, Lat. 20³4' 36.7"; Lon. 92 20' 9.5").

Remarks: The elongate shell has four to five whorls and a deep suture. The spire is relatively high due to the rapid increase in size of the whorls. On the last half of the body whorl a strong keel ends in a distinct aperture tooth. The aperture is wide. The height of the shell is up to $7.5 \mathrm{~mm}$ and maximum diameter is $6 \mathrm{~mm}$. Type locality of this species is Atlantic Ocean and Mediterranean Sea.

\author{
Super family: Cavolinioidea \\ Family: Cavoliniidae \\ Genus: Cavolinia
}

Type species: Cavolinia uncinata (d'Orbigny 1836)

Plate 1, Figs 14, 15 (Uttar para 2, Lat.20³4' 33"; Lon. 92 20' 13.4").

Remarks: This species large and uncoiled cosomatous pteropod. Though the specimen is small in size, the most typical characters are the long caudal spine which is curved dorsally. The lateral spines are towards the caudal portion and the line between the tips of caudal and lateral spines is not regularly curved. Faint growth lines and transverse striation near the aperture is present on the shell. This species is found in Cape Verde, Aruba, Caribbean Sea, Indo-Pacific, New Zealand Exclusive Economic Zone. In Indian sub-continent it is available in Eastern Bay of Bengal (Nair et al. 1991). 
Genus: Diacria

Type species: Diacriatrispinosa (Blainville1821)

Plate 1, Fig. 16 (Chera Dwip 2, Lat. 20³4' 54.3"; Lon. 92²0' 13.2").

Remarks: The slender shell is uncoiled but bilateral symmetrical with a long caudal spine. Relatively large shell, the lateral spines are straight, the caudal spine is proportionally short. The shell aperture is wide, length of the shell is up to $9 \mathrm{~mm}$ and width up to 10.5 $\mathrm{mm}$. This species is exclusively marine, phytophagous and epipelagic in cold water.This forma is mainly found in the North Atlantic Ocean between 40 and $70^{\circ} \mathrm{N}$ (Van der Spoel and Dadon1997).

\title{
Family: Creseidae \\ Genus: Creseis
}

Type species: Creseisclava (Rang 1828)

Plate 1, Figs 17, 18 (Uttar para 5, Lat. 20³4' 49"; Lon. 92 20' 11").

Remarks: The shell is straight up to $6 \mathrm{~mm}$ long with a diameter of about $1 \mathrm{~mm}$. The embryonic shell is rounded at its end. The caudal part in profile has two or more swelling caused by transverse rings below a concave portion ending in the perfectly round embryonic end. This species is known from the Late Quaternary of the Red Sea (Pleistocene-Holocene). This forma is mainly found in warm waters of the Atlantic, Indian and Pacific oceans.

\author{
Super family: Actionoidea \\ Family: Apulstridae \\ Genus: Hydatina
}

Type species: Hydatinaalbocincta (van der Hoeven 1839)

Plate 1, Figs 19, 20 (Chera Dwip 1, Lat. 20³4' 47.8"; Lon. 92 20' 19.2").

Remarks: Shell is medium sized, thin and globose. Body whorl is large with many microscopic colored growth striae. Radial coloration consists of lines or broad bands. Spire consists of two or three exposed whorls. Aperture is large with more or less ear shaped. The outer lip is thin and slightly sinuous. All the species of Hydatina are found in tropical Indo-Pacific region and in tropical Atlantic Ocean.

Order: Stylommatophora

Family: Ariophantidae

Genus: Macrochlamys

Type species: Macrochlamysopipara (Godwin 1956)

Plate 2, Figs 1, 2 (Uttar para 1, Lat.20³4' 47.8"; Lon. 92²0' 19.2"). 

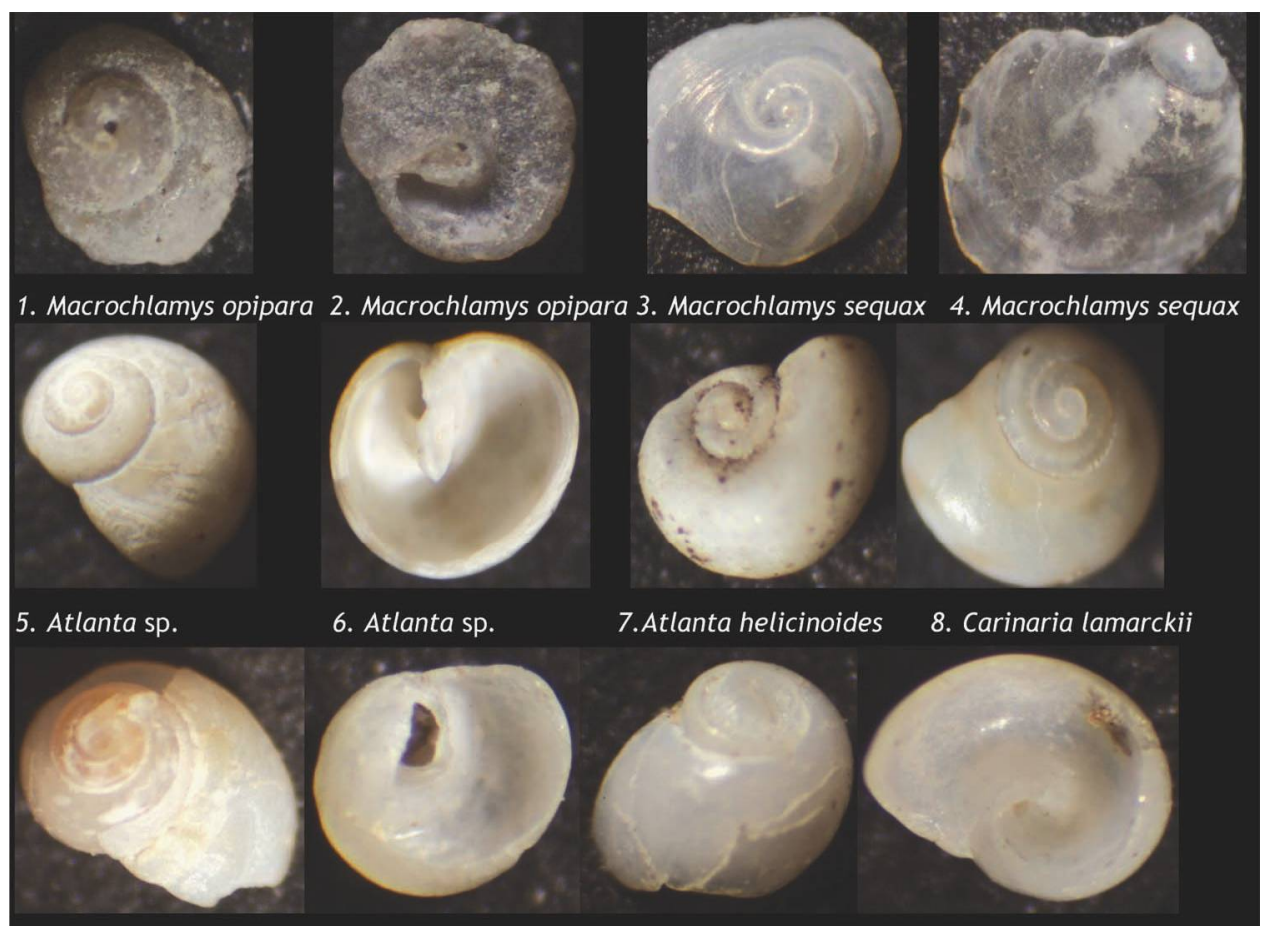

6. Atlanta sp.

7.Atlanta helicinoides

8. Carinaria lamarckii

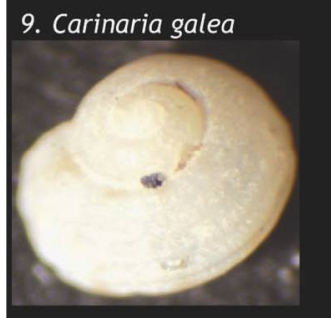

10. Carinaria galea

11. Natica gualteriana 12. Natica gualteriana
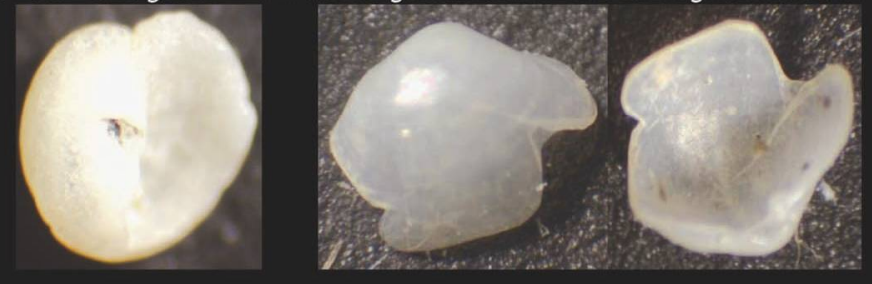

13. Firoloida desmarestia

14. Firoloida desmarestia

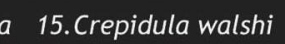

16. Crepidula walshi
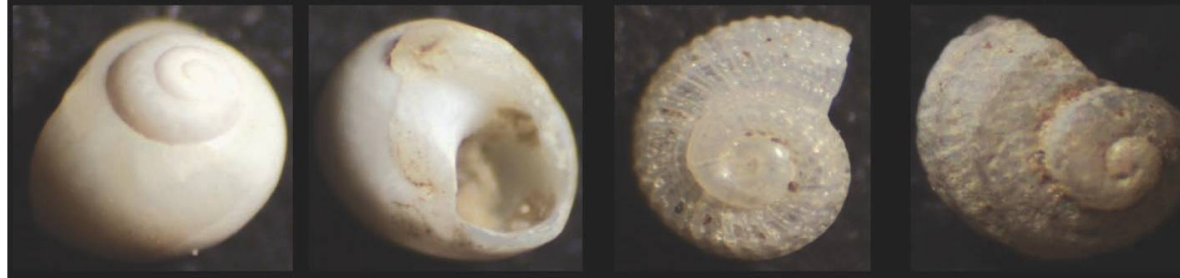

17. Bellamya crassa

18. Bellamya crassa

19. Pterocyclus rupestris 20. Astralium semicostata

Plate 2. Selected pteropods recovered from Saint Martin's Island. 
Remarks: Shell medium, perforate, sub globosely depressed, surface smooth, polished and translucent. Five body whorls, slightly convex above, last whorl is rounded. Aperture is oblique, broadly lunate. Average shell length is $9 \mathrm{~mm}$, width is $14 \mathrm{~mm}$ and aperture length is $8 \mathrm{~mm}$. It is mainly found in the moist parts of the world such as India, Myanmar, Sri Lanka, Bangladesh and some other Asian countries.

\section{Genus: Macrochlamys}

Type species: Macrochlamyssequax (Benson 1836)

Plate 2, Figs 3, 4 (Uttar para 1, Lat.20³4' 47.8"; Lon. 92 20' 19.2").

Remarks: Shell medium, thin, perforate, depressed, polished, spire low, sides slightly concave, closely oblique strie and spiral lines are finely decussate. Aperture is slightly oblique, broadly lunate. Average shell length, width, aperture length and width is 9, 16, 9 and $6 \mathrm{~mm}$, respectively (Thakuret al. 2012).

\section{Subclass: Caenogastropoda \\ Order: Littorinimorpha \\ Super family: Pterotracheoidea \\ Family: Atlantidae \\ Genus: Atlanta \\ Type species: Atlanta sp.}

Plate 2, Figs 5, 6 (Chera Dwip 4, Lat. 20³8' 9.6"; Lon. 92 19' 22.2").

Remarks: A relatively large, highly spired, conical shell with up to four whorls. The whorls are flat-topped at the sutures, giving step shape in side on profile. The umbilicus is large and open. The species are cosmopolitan and mainly found in Indo-Pacific, Pacific Ocean, Indo-Atlantic and the Atlantic Ocean.

\section{Genus Atlanta}

Type species: Atlanta heliconoides (Souleyet 1852 in Newman 1990)

Plate 2, Fig. 7 (Chera Dwip 5, Lat. 20³4' 18.7"; Lon. 92 19' 36.6").

Remarks: This is a small species (maximal shell diameter of $2 \mathrm{~mm}$ ). The last whorl in adult shells is broadly oval to round. The keel is moderately tall and rounded in undamaged specimens, with a posteriorly-slanted corrugated texture. The spire is low conical, consisting of four to five whorls. The species shares many similarities with A. inflata, but is immediately distinguishable by its eye morphology. The species is cosmopolitan in tropical to subtropical waters, and is limited to the upper $100 \mathrm{~m}$ of the water column in Hawaiian waters. 


\title{
Family: Carinariidae
}

Genus: Carinaria

Type species: Carinarialamarcki (Blainville 1821)

Plate 2, Fig. 8 (Uttar para 1, Lat. 20³7' 30.9"; Lon. 92 19' 35.7").

Remarks: The shell is broad pyramidal shaped (maximum body length is $220 \mathrm{~mm}$ ) with the protoconch, the only part with whorls on top. The body whorl is large with coarse transverse striation. The body is almost completely transparent and can never withdraw into the shell. The shell is low conical with a high keel. It is a cosmopolitan species with a wide north-south range between $60^{\circ} \mathrm{N}$ and $45^{\circ} \mathrm{S}$. In the Mediterranean it is common everywhere and penetrates deep into the Caribbean.

Genus: Carinaria

Type species: Carinariagalea (Benson 1836)

Plate 2, Figs 9, 10 (Uttar para 1, Lat. 20³7' 30.9"; Lon. 92 19' 35.7").

Remarks: This is a very large shelled pelagic snail, can be up to $5 \mathrm{~cm}$ long with an almost completely transparent body. The shell is high conical with a high keel. Only the broad triangular visceral nucleus is darkly pigmented. The shell is less strongly curved backwards than in Carinarialamarcki. Embryonic shell, with three to five whorls. Body length is up to $50 \mathrm{~mm}$.This species is endemic to the Indo-Pacific Ocean and it shares its distribution pattern with Carinaria cristata. A much greater population is found only in the Tasman Sea.

\author{
Superfamily: Naticoidea \\ Family: Naticidae \\ Genus: Natica
}

Type species: Naticagualteriana (Recluz 1844)

Plate 2, Figs 11, 12 (Uttar para 5, Lat. 20³4' 49"; Lon. 92 20' 11").

Remarks: Small shell (maximum shell length $32 \mathrm{~mm}$ ), solid globose with inflated body whorl and elevated spire, pointed apex surface smooth and glossy. Aperture large and semicircular. Surface ash white, ornamented with wavy vertical lines, apex partially tinged with pale bluish grey, umbilical space white and body whorl with a white band. Indo-West Pacific from southern India, Sri Lanka, the Philippines and Taiwan to Melanesia and Indonesia. 
Super family: Pterotracheoidea

Family: Pterotracheidae

Genus: Firoloida

Type species: Firoloidadesmarestia (Lesueur 1817).

Plate 2, Figs 13, 14 (Chera Dwip 3, Lat. 20³7' 30.9"; Lon. 92 19' 35.7").

Remarks: This is a medium sized naked pelagic snail with an almost completely transparent body. The intestine is frequently full and visible. It has a small dextrally coiled shell with about 3 whorls, regularly increasing in width. The suture is clear but not very deep. The aperture is oval to round. The shell is yellow-whitish and the surface is smooth. Body length of the species is up to $40 \mathrm{~mm}$. This species is found between $40^{\circ} \mathrm{N}$ and $40^{\circ} \mathrm{S}$ which is slightly further southwards than most Heteropoda.

\section{Superfamily: Calyptraeoidea \\ Family: Calyptraeidae \\ Genus: Crepidula}

Type species: Crepidulawalshi (Reeve 1859).

Plate 2, Figs 15, 16 (Chera Dwip 5, Lat. 20³8' 9.6"; Lon. 92 19' 36.6").

Remarks: Shell small (maximum shell length $9 \mathrm{~mm}$ and $23 \mathrm{~mm}$ in diameter), elongateovate, flattened, spire obsolete towards the posterior edge, margins irregular, internal shelf flattened and partly covering the aperture, arises from below the apex. Surface with fine concentric striae and coarse growth lines.

Order: Architaenioglossa

Super family: Cyclophoroidea

Family: Viviparidae

Genus: Bellamya

Type species: Bellamyacrassa (Benson 1836)

Plate 2, Figs 17, 18 (Uttar para 1, Lat. 20³7' 30.9"; Lon. 92 19' 35.7").

Remarks: Shell small, thicker, globose with fine transverse striations. Umbilicus perforate, spire short and blunt. Umbilical opening is prominent, generally impressed, suture often canaliculated. Aperture sub oval, columella arched.

Family: Cyclophoridae

Genus: Pterocyclos

Type species: Pterocyclosrupestris (Benson 1832)

Plate 2, Fig. 19 (Chera Dwip 3, Lat. 20³4' 54.9"; Long. 92 20' 14.3"). 
Remarks: Average shell length, width, aperture length, width are about 5, 11, 6, $4 \mathrm{~mm}$, respectively (Thakur et al. 2012, Mitra 2014). Shell small, nearly transparent, depressed with a scarcely raised spire, finely striate. Last whorl descending moderately, aperture circular. Shell is whitish marked with zigzag chocolate lines, both above and below. Freshwater pteropod. Plays an important role in the terrestrial ecosystem as a scavenger.

\author{
Subclass: Vetigastropoda \\ Super family: Trochoidea \\ Family: Turbinidae \\ Genus: Astralium
}

Type species: Astraliumsemicostata (Kiener 1850).

Plate 2, Fig. 20 (Chera Dwip 6, Lat. 20³4' 47.3"; Long. 92 ${ }^{\circ} 20^{\prime} 14^{\prime \prime}$ ).

Remarks: Average shell length, width, aperture length and width are about 19, 20, 13 and $9 \mathrm{~mm}$ respectively (Ahmed 1995, Rao 1968). Shell small, cone shaped, longitudinal folds across the surface of the whorls. Shell sculptured with oblique axial nodules, distinct just above the suture and body shoulder. Apex not so sharp, aperture oblique ovate, covered by a flat base. Creamy white body surface with creamy spots. Wide spread in the Indian Ocean, Myanmar, Sri Lanka, the Philippines and Australia.

\title{
Result and Discussion
}

Species of Uttar para part: The investigation of pteropods in the Saint Martin's Island concluded to final analysis of total 41 species. Among the total species, 39\% of the samples were from Thecosomata order of Heterobranchia subclass under the class of Gastropoda. The Thecosomes included 6 families, 9 genus and 16 species. The distribution of pteropods is mainly influenced by the depth of the ocean (van Straten 1972). The abundance of pteropods within different water masses depends upon certain physical and chemical properties and also by the adaptive capacities of different species. In case of Thecosome pteropods, the abundance depends on the process of calcification to grow their shells which consist of aragonite and calcium carbonate. Therefore the saturation of carbonate ions in the water is very important to their survival. Their body is made up of an aragonite and calcium carbonate shell and so they are very sensitive to ocean acidification caused by the anthropogenic $\mathrm{CO}_{2}$ and other oceanic processes (Comeau et al. 2009) and also play a vital role in the cycling of carbon and carbonate.

During the field investigation, most of the pteropod species of Thecosomata were found in the Saint Martin's part of the field area which is situated in the northern part known as 
Uttar para. Within this part Thecosomes were abundant in 'Uttar para 1' station as 6 species were found there. Five species were found each in 'Uttar para 2'and 'Uttar para 5' stations, 2 species each were found at 'Uttar para 3' station and 1 species was found at 'Uttar para 4' station, 'Chera Dwip 1' station and 'Chera Dwip 7' station. Abundance of Thecosomata in Uttar para part are very young, most of them are from Holocene. All of them are predominantly shallow water species. Gleba cordata from 'Uttar para 2' and Peracle bispinosa from 'Uttar para 3' stations are exclusively warm water species. Hence their presence indicates shallower water. On the other hand 3 freshwater species of Stylommatophora order, namely Macrochlamys opipara and Bellamya crassa were found near the ferry ghat at 'Saint Martin 1' station which indicates availability of fresh water or very low percentage of salinity of the ocean water. As the Thecosomes are being survived in this region, it indicates the threat of acidification is lesser in this area. But further detailed studies on the shell morphology and their rate of decay can specify the condition of acidification. Overall it can indicate the threat of acidification is not concerning in this region though it can be concerning in near future.

The species of Chhera Dwip part mostly comprises of different orders and, families and genus than the species of Uttar para part. It is known that the abundance of a certain species depends on the depth of the ocean water. Chheradip is further ahead of the Uttar para towards the Bay of Bengal and contains deeper water than the previous area. So we can notice the changing in the abundance of different pteropod species with the increasing depth towards Chera Dwip.

The samples in this region includes one order, one family and one genus of Heterobranchia subclass, 3 orders, 8 family and 8 genus of Caenogastropoda subclass and one family and genus of Vetigastropoda subclass. Marine Caenogastropods including Littorinimorpha, Neogastropoda and Architaenioglossa orders of pteropods are abundant here. Among them, Littorinimorpha has 8 species, Architaenioglossa has 4 species and Neogastropoda has only 1 species. Thecosomes were abundant in Saint Martin part but in this region Thecosomes are infrequent. Among the total number of Thecosomes, only $19 \%$ are found here and remaining $81 \%$ are found in Uttar para part. In Chera Dwip part they were found only in 'Chera Dwip and 'Chera Dwip station. It suggests that the oceanic condition is more suitable in Uttar para area or shallower water than in Chera Dwip part which is comparatively deeper area. The reason behind it could be the threat of acidification, variation in salinity etc. Further studies in this region could be helpful to understand clearly about the decrease of the Thecosomes and in this way it is possible to construct the palaeoclimatic conditions, salinity, acidification, sea level up down etc. A 
thorough study over a year on pteropods in this region would be very helpful to analyze the seasonal variation of sea level rise and corresponding climatic threat in this region.

\section{Conclusion}

The Saint Martin's Island is a great resource of our country. In recent years global climate change poses a high risk to the biodiversity of coral reefs of St. Martin's. The major threats to the coral reefs are high levels of sedimentation, cyclones, storm surges and beach erosion. Global warming is a matter of major concern for coral reefs of this island as elsewhere. The purpose of the study was to identify the species of pteropods in this region and know about their characteristics. The study reveals a high abundance of The cosomes in this region. At present, The cosomes are being used as the indicator of ocean acidification in many areas of the world. So, further detailed study on this can reveal significant indication about the potential disaster in this region.

\section{References}

Afrin, S., N. Sultana and M.T. Islam. 2013. Exploring the Potentials of 'Culture-friendly' Tourism: An Empirical Study in the Saint Martin's Island. American International Journal of Research in Humanities, Arts and Social Sciences 3: 200-204.

Ahmed, M. 1995. An Overview on the coral reef ecosystem of Bangladesh. Bangladesh Journal of Environmental Science 1: 67-73.

Aiyar, R. G., S. Menon and M. G.K. Menon.1936. Plankton records for the year 1929 and 1930. Journal. Madras, Univ. 8: 97-139.

Almogi-Labin, A. 1982. Stratigraphic and paleoceanographic significance of Late Quaternary pteropods from deep-sea cores in the Gulf of Aqaba (Elat) and northernmost Red Sea. Marine Micropaleontology 7: 53-72.

Almogi-Labin, A., C. Hemelben, D. Meischner and H. Erlenkeuser 1991. Paleoenvironmental events during the last 13,000 years in the central Red Sea as recorded by pteropoda. Paleoceanography and Paleoclimatology 6: 83-98.

Banglapedia, 2015. The National Encyclopedia of Bangladesh, Asiatic Society of Bangladesh.

Bé, A.W.H., Gilmer, R.W., 1977. A zoogeographic and taxonomic review of euthecosomatous pteropoda. In: Ramsay, A.T.S. (Ed.), Oceanic Micropalaeontology. Academic Press, London, pp. 733-808.

Berner, R. A. 1977. Sedimentation and dissolution of pteropods in the Ocean. In: Andersen, N. R. and Mala-hoff, A., eds., The Fate of Fossil Fuel $\mathrm{CO}_{2}$ in the Oceans. Plenum Press, New York, p. 323-343.

Benson, W.H. 1832. Account of new genus of land snails, allies to the genus Cyclostoma, of Lamarck; with a description of species found on the outlying rock of the Rajmahal. Journal of the Asiatic Society of Bengal.

Benson, W.H.1836. Descriptive catalogue of a collection of land- and freshwater shells, chiefly contained in the Museum of the Asiatic Society. Journal of the Asiatic Society of Bengal. 
Bhattacharjee, D., S.K. Ghosh, S. Rakshit and T.K. Mallik. 2002. Evidence of late Quaternary climatic changes revealed by pteropod record around Car Nicobar Island, Andaman Sea, Gondwana Geol.Magz. Spl. 4: 157-167.

Bhattacharjee, D. 2005. Pteropod preservation profiles in seabed sediments off Middle Andaman Island in Andaman Sea, Indian Journal of Marine Science, 34: 259-266.

Blainville, H.M.D. de. 1821. Hyale, Hyalea(Malacoz), In: Dictionnaire des Sciences Naturelles (F. Cuvier, ed.), vol. 22. Levrault, Strasbourg \& Le Normant, Paris., available online at http://biodiversitylibrary.org/page/23050902 pp. 65-83.

Boltovskoy, E. 1978. Late Cenozoic benthic foraminifera of the Ninety east Ridge (Indian Ocean).

Chowdhury, S. Q. 2012. "St. Martin's Island". In: Islam, Sirajul; Jamal, Ahmed A. Banglapedia: National Encyclopedia of Bangladesh (Second ed.). Asiatic Society of Bangladesh.

Comeau, S., G. Gorsky, R. Jeffree J.L. Teyssie and J.P. Gattuso. 2009. Impact of ocean acidification on a key Arctic pelagic mollusc (Limacinahelicina). Biogeosciences 6: 18771882.

Comfort, A. 1957. The duration of life in Mollusks. Journal of Molluscan Studies, 32: 219-241.

DoZ (Department of Zoology). 1997. Survey of Fauna, Draft Final Report, National Conservation Strategy Implementation Project1 (Dhaka: Ministry of Environment and Forest, Government of the People's Republic of Bangladesh).

Fabry, V.J., B.A. Seibel, R.A. Feely and J.C. Orr 2008. Impacts of ocean acidification on marine fauna and ecosystem processes. ICES Journal of Marine Science, 65(3): 414-432.

Feely, R.A., S.C. Doney and S.R Cooley. 2009. Ocean acidification: Present conditions and future changes in a high- $\mathrm{CO}_{2}$ world. Oceanography 22: 1-47.

Gehrels, W. R., H.M. Roe and D.J. Charman 2002. Foraminifera, testate amoebae and diatoms as sea-level indicators in UK saltmarshes: A quantitative multiproxy approach. W. Roland Gehrels, Helen M. Roe and Dan J. Charman Journal of Quaternary Science. 16(3): 201220.

Gilmer, R.W. and G.R. Harbison. 1991. Diet of Limacina helicina (Gastropoda: Thecosomata) in Arctic waters in midsummer. Mar. Ecol. Prog. Ser. 77: 125-134.

Godwin, H. 1956. The History of the British Flora. Cambridge University Press, London, 384 pp.

Herman, Y. 1968. Evidence of climatic changes in Red sea cores. 7th INQUA Congress Proceedings, 8: 325.

Herman, Y. and Rosenberg, P. E. 1969. Pteropods as bathymetric indicators. Marine Geology 7: 169-173.

Horton, B.P., P. Larcombe, S.A. Woodroffe, J.E. Whittaker, M.R. Wright and C. Wynn. 2003. Contemporary foraminiferal distributions of a mangrove environment, Great Barrier Reef coastline, Australia: Implications for sea-level reconstructions. 198: 225-243

Hunt, B.P.V. and G.H. Hosie 2006. The seasonal succession of zooplankton in the Southern Ocean south of Australia, part I: The seasonal ice zone. Deep-Sea Research 53: 1182-1202, doi:10.1016/j.dsr.2006.05.001

Janssen, A. W., 2005. Development of Cuvierinidae (Mollusca, Euthecosomata, Cavolinioidea) during the Cainozoic: A non-cladistic approach with a reinterpretation of recent taxa. Basteria 69: $25-72$.

Jeffreys, J.G. 1858. Gleanings in British conchology. Natural History, 2.

Kiener, 1850. Accessed through: World Register of Marine Species at: http://www.marinespecies. org/aphia.php? $\mathrm{p}=$ taxdetails\&id=717327 on 2018-12-06.

Lalli C.M., R.W. Gilmer. 1989. The thecosomes. shelled pteropods. In: Lalli CM, Gilmer RW, editors. Pelagic snails. The biology of holoplanktonic gastropod molluscs. California: Stanford University Press: 58-166.

Lesueur, R. 1817. Accessed through: World Register of Marine Species at: http://www. marinespecies.org/aphia.php?p=taxdetails\&id=139943 on 2018-12-06 
Mitra, A. 2014. Bridging the gap between marine biogeochemical and fisheries sciences; configuring the zooplankton link. Progress in Oceanography 129: 176-199.

Monterosato, T.D. 1875. Nuova rivista della Conchiglie Mediterranee. (Catalogo delle Conchiglie Mediterrance). Atti dell'Accademia Palermitana di Scienze, Letter ed Arti, Palermo 5(2): $1-50$.

Nair, R.R., V. Ramaswamy, S. Manganini and V. Ittekkot. 1991. Lithogenic fluxes to the deep Arabian Sea measured by sediment traps. Oceanographic Research 38: 169-184.

Newman, L.J. 1990. The taxonomy, distribution and biology of Atlanta gaudichaudi Souleyet, 1852 (Gastropoda, Heteropoda) from the Great Barrier Reef, Australia. Am Malacol. 8: 85-94.

Niebuhr, C. 1776. Voyage en Arabie \& en d'autres Pays circonvoisins. books.google.com

Orbigny, A.d'. 1836. Voyage dansl'Amériqueméridionale (le Brésil, la républiqueorientale de l'Uruguay, la république Argentine, la Patagonie, la république du Chili, la république de Bolivia, la république du Pérou), exécuté pendant les années 1826, 1827, 1828, 1829, 1830, 1831, 1832 et1833, Mollusques. Paris (Bertrand), 5(3).

Palmer A.J.M. and W.H. Abbott. 1986. Diatoms as indicators of sea-level change. In: van de Plassche O. (eds) Sea-Level Research. Springer, Dordrecht.

Pelseneer, P. 1965.Report on the Pteropoda Collected by HMS Challenger During the Years 1873-76: the Thecosomata. Johnson Reprint Corporation.

Rang P.C. 1828. Notice sur quelques mollusques nouveaux appurtenant au genre Cleodore, et etablissement at monographic des sous-genre Creseis. Annales des Sciences Naturelles 13: 302-319, pl. 17-18.

Rao, S.N.V. 1968. Report on a collection of wood-boring molluscs from Mahanadi estuary, Orissa, India. Proc. Symposium on Mollusca. Mar. Biol. Ass. India.

Recluz, C.A. 1844. Descriptions of new species of Navicella, Neritina, Nerita, and Natica in the cabinet of H. Cuming, Esq.Proceedings of the Zoological Society of London.

Reeve, L.A. 1859. Conchologica Iconica. Vol. 11.

Reiss, Z., B. Luz, A. Almogi-Labin, and E. Halicz. 1980. Late Quaternary Paleoceanography of the Gulf of Aqaba (Elat), Red Sea 1.Quaternary Research 14: 293-308.

Sakthivel, M. 1976. Geographical and seasonal distribution of Euthecosomata (Pteropoda, Gastropoda) in the Indian Ocean. Meteor Forsch.Ergebniss 23: 1-22.

Scott and Medioli, 2004. Monitoring in Coastal Environments Using Foraminifera and Thecamoebian Indicators. Cambridge Univ. Press ISBN 0-511-03827-5.

Singh, A.D. and Rajaram 1997. Distribution of Pteropods in surface sediments from the continental shelf of north Kerala. Journal of Geological Society of India, 49: 81-84.

Singh, A.D., K.K. Ramachandran, M. Samusuddin, N.R. Nisha, and V.Haneeshkumar 2001. Significance of pteropods in deciphering the late Quaternary sea-level history along the south western Indian shelf. Geo-Marine Letters 20: 243-251.

Souleyet, F.L. 1852. In: RANG P.C.A.L. and SOULEYET F.L.A.- Histoire naturelle des mollusques pteropodes. Monographie comprenant la description de totues les especes. Bailliere, Paris: 1-86.

Thakur, R., R. Singh, and N. Jain. 2012. Evaluation of antibacterial activity of Sphaeranthus indicus L. leaves. J. Pharm. Res. 5(8): 4382-4388.

Tomascik, T. 1997. 'Management Plan for Resources of Narikel Jinjira (St. Martin's Island) Final Report', Prepared for the National Conservation Implementation Project-1, Ministry of Environment \& Forest, Government of the Peoples' Republic of Bangladesh.

Van der Hoeven, 1839. Accessed through: World Register of Marine Species at: http://www. marinespecies.org/aphia.php?p=taxdetails\&id=510326 on 2018-12-06.

van der Spoel S. and L. Diester 1978. Late pleistocene pteropod-rich sediment layer in the northeast atlantic and protoconch variation of Clio pyramidata Linné 1767. Palaeogeography, Palaeoclimatology, Palaeoecology 24: 85-109. 
van der Spoel, S. and J.R Dadon 1997. Pteropoda. In: Boltovskoy, D. (Ed.), South Atlantic Zooplankton. Backhuys Publishers, Leiden, The Netherlands. pp. 649-706.

Van Straaten, L. M.J.U. 1972. Holocene stages of oxygen depletion in deep waters of Adriatic Sea, In: Stanley, D.J. (ed.), The Mediterranean Sea; Anatural sedimentation laboratory, Dowden,Hutchison \& Ross, Inc., Stroudsburg. p. 631-643.

Wang, P., L. Wang, B. Yunhua and J. Zhimi. 1995. Late Quaternary paleoceanography of the South China Sea: surface circulation and carbonate cycles. Marine Geology, 127: 145-165.

Warrick, R. A., A.H. Bhuiya, and M.Q. Mirza. 1993. Climate Change and Sea-level Rise: The Case of the Coast. Briefing Document No. 6, Bangladesh Unnayan Parishad (BUP), Dhaka.

Woodward, S.P. 1854. A manual of the Mollusca; or A rudimentary treatise of recent and fossil shells 2: 207. London.

Yusuke, A. 2011. Oligocene pteropods (Gastropoda: Thecosomata) from the Kishima Formation, Saga Prefecture, southwest Japan. Revista Mexicana de Ciencias Geológicas 28: 245-253.

(Revised copy received 05.04.2019) 